\title{
Laboratory Evaluation of Natural and Synthetic Aromatic Compounds as Potential Attractants for Male Mediterranean fruit Fly, Ceratitis capitata ${ }^{\dagger}$
}

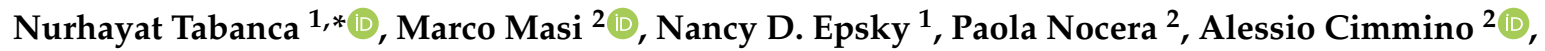 \\ Paul E. Kendra ${ }^{1}{ }^{1}$, Jerome Niogret ${ }^{3}$ and Antonio Evidente ${ }^{2, *}$ \\ 1 United States Department of Agriculture, Agricultural Research Service, Subtropical Horticulture Research \\ Station (SHRS), Miami, FL 33158, USA \\ 2 Department of Chemical Sciences, University of Naples "Federico II", Complesso Universitario Monte S. \\ Angelo, Via Cintia 4, 80126 Napoli, Italy \\ 3 Niogret Ecology Consulting LLC, 13601 Old Cutler Road, Miami, FL 33158, USA \\ * Correspondence: Nurhayat.Tabanca@ars.usda.gov (N.T.); evidente@unina.it (A.E.); \\ Tel.: +1-(786)-5737077 (N.T.); +39-(081)-2539178 (A.E.) \\ + This work was produced by US government employees and is in the public domain in the US.
}

Academic Editor: Jesus Simal-Gandara

Received: 30 May 2019; Accepted: 27 June 2019; Published: 29 June 2019

\begin{abstract}
Ceratitis capitata, the Mediterranean fruit fly, is one of the most serious agricultural pests worldwide responsible for significant reduction in fruit and vegetable yields. Eradication is expensive and often not feasible. Current control methods include the application of conventional insecticides, leading to pesticide resistance and unwanted environmental effects. The aim of this study was to identify potential new attractants for incorporation into more environmentally sound management programs for C. capitata. In initial binary choice bioassays against control, a series of naturally occurring plant and fungal aromatic compounds and their related analogs were screened, identifying phenyllactic acid (7), estragole (24), o-eugenol (21), and 2-allylphenol (23) as promising attractants for male C. capitata. Subsequent binary choice tests evaluated five semisynthetic derivatives prepared from 2-allylphenol, but none of these were as attractive as 2-allylphenol. In binary choice bioassays with the four most attractive compounds, males were more attracted to $o$-eugenol (21) than to estragole (24), 2-allylphenol (23), or phenyllactic acid (7). In addition, electroantennography (EAG) was used to quantify antennal olfactory responses to the individual compounds (1-29), and the strongest EAG responses were elicited by 1-allyl-4-(trifluoromethyl)benzene (11), estragole (24), 4-allyltoluene (14), trans-anethole (9), o-eugenol (21), and 2-allylphenol (23). The compounds evaluated in the current investigation provide insight into chemical structure-function relationships and help direct future efforts in the development of improved attractants for the detection and control of invasive C. capitata.
\end{abstract}

Keywords: kairomone; o-eugenol; estragole; phenyllactic acid; attractants; invasive species; electroantennography

\section{Introduction}

Tropical fruit flies (Diptera: Tephritidae) are among the most economically important pests that threaten global agriculture [1]. Among the exotic fruit flies, the Mediterranean fruit fly (medfly), Ceratitis capitata (Wiedemann), is considered one of the most destructive agricultural pests because of its direct damage to many varieties of fruits and vegetables [2-4]. The species apparently originated in sub-Saharan Africa; however, increased human mobility and trade in agricultural commodities have increased the incidence of the introduction of exotic fruit flies to the United States [5]. Medfly was first 
detected in Hawaii in 1910 and in Florida in 1926 and later in 1956, 1962, 1963, 1967, 1981, 1990, 1997, 1998, and $2010[5,6]$. Eradication campaigns in response to detections are extremely laborious and costly [5]. For example, medfly eradication in the Tampa Bay area (Florida) in 1997 cost \$US 25 million, and eradication efforts during the past 25 years in California cost nearly \$US 500 million [6]. The embargo, loss of market, quarantine regulations, and subsequent job losses further contribute to the overall economic impact of fruit fly incursions in many countries [5]. In March 2015, an outbreak of medfly was reported for the first time in the Dominican Republic and a subsequent ban imposed by the United States resulted in losses of about \$US 40 million to Dominican producers [7]. In addition to economic concerns, the high occurrence of pesticide residues in fruits and vegetables and the use of postharvest fumigants like methyl bromide are not desirable by consumers $[8,9]$.

Current management strategies for medfly include the use of trimedlure-baited traps for pest detection and monitoring and the release of sterile male flies for population suppression [2-4,10-12]. Trimedlure, tert-butyl 4(and 5)-chloro-2-methylcyclohexane- 1-carboxylate $\left(\mathrm{C}_{12} \mathrm{H}_{21} \mathrm{ClO}_{2}\right)$, is a synthetic attractant with a mixture of different diastereomers. Of these isomers, $(+)$-trimedlure- $\mathrm{C}$ was found to be the most attractive [12]. The development of male lures for C. capitata has a long history of success. Angelica archangelica L. seed oil was used extensively for survey and detection during the eradication program in Florida in $1956[12,13]$. Over a decade later, $\alpha$-copaene, a natural sesquiterpene hydrocarbon, was identified as the main attractant in angelica seed oil and was reported to be $2-5$ times more attractive for $C$. capitata than trimedlure in field tests. While it is highly attractive, $\alpha$-copaene has limited practical use as a field lure due to its structural complexity and difficulties with synthesis [12]. A study reported by our group also found that the concentration of $\alpha$-copaene in host plants was correlated with the short-range attraction of male $C$. capitata but not with long-range attraction or olfactory response, as measured by electroantennography (EAG) [14]. Previous research investigated six essential oils—ginger root, orange, manuka, cubeb, angelica seed, and tea tree oil—for their attractancy in laboratory and field tests and EAG response of sterile males and wild C. capitata. Results showed that ginger root oil was the most attractive oil in field cage bioassays and elicited the greatest EAG response [15]. These essential oils were further evaluated in short-range bioassays, and tea tree oil, when diluted to $10 \mu \mathrm{g} / \mu \mathrm{L}$, showed the highest attraction of sterile male medflies [16].

Although considerable progress has been made to identify food-based attractants and host-based kairomones for exotic fruit flies, there is still a need for new and effective attractants to improve the detection and control of invasive medflies. Here, we evaluate a series of aromatic compounds and phenols, a group of chemicals well-known as plant and microbial bioactive metabolites [17,18].

Our ongoing studies focus on the identification of alkaloids from four native South African Amaryllidaceae species_Crinum buphanoides (Welw. ex Baker), Crinum graminicola (I. Verd.), Cyrtanthus mackenii (Hook. f.), and Brunsvigia grandiflora (Lind1.) [19]—and nine alkaloids belonging to the lycorine subgroup along with the isocrabostyril, tazettine, and crinine subgroups have been isolated [20]. Interestingly, two non-alkaloid compounds, piceol (4-hydroxyacetophenone, 1, Figure 1) and acetovanillone (apocynin, 2, Figure 1), were isolated from C. buphanoides, while only the former was isolated from C. graminicola [21]. In addition, some phytotoxic phenols have been isolated recently from phytopathogenic fungi, including tyrosol (3) and resorcinol (4) (Figure 1), purified from the culture filtrates of Dothiorella vidmadera (DAR78993), a pathogen involved in the Botryosphaeria dieback of grapevine [22] and 4-hydroxybenzaldehyde (5, Figure 1) purified from the solid cheatgrass (Bromus tectorum L.) culture of a Fusarium strain belonging to the F. tricinctum (Corda) species complex [23].

The findings above prompted the current collaboration to test these compounds for semiochemical activity using a laboratory strain of $C$. capitata. Specifically, we (i) investigated short-range attraction of male $C$. capitata to 29 structurally related natural and synthetic aromatic compounds (Figure 1) using small cage laboratory bioassays, (ii) conducted EAG analyses to quantify olfactory chemoreception of these compounds, and (iii) discuss the structure-activity relationships of these compounds to facilitate identification of promising candidate attractants for future research. In addition, we describe the synthesis of five derivatives of 2-allylphenol (23) used in this study. 
<smiles>CC(=O)c1ccc(O)cc1</smiles>

1, piceol<smiles>COc1cc(C(C)=O)ccc1O</smiles>

2, acetovanillone<smiles>OCCc1ccc(O)cc1</smiles>

3, tyrosol<smiles>Oc1cccc(O)c1</smiles>

4, resorcinol<smiles>O=Cc1ccc(O)cc1</smiles>

5, 4-hydroxybenzaldehyde<smiles>Cc1ccc(O)c(O)c1</smiles>

6, 4-methylcatechol<smiles>O=C(O)[C@H](O)Cc1ccccc1</smiles>

7, phenyllactic acid<smiles>C=CCc1ccccc1</smiles>

9, trans-anethole<smiles>C=CCc1ccc(C(F)(F)F)cc1</smiles>

11, 1-allyl-4-(trifluoromethyl)<smiles>C=CCc1ccc(O)cc1</smiles>

12, 4-allylphenol (chavicol)<smiles>C=CCc1cc(OC)c(OC)c(OC)c1</smiles><smiles>CC(=O)c1cccc(O)c1</smiles>

16, 3-hydroxy acetophenone

15, 4-allyl-2,6trimethoxybenzene<smiles>CCCc1ccc(O)c(OC)c1</smiles><smiles>C=CCc1ccc(OC)c(OC)c1</smiles>

20, 4-allyl-1,2-dimethoxybenzene (methyl eugenol)

19, 2-methoxy 4-propylphenol<smiles>C=CCc1ccccc1O</smiles>

23, 2-allylphenol<smiles>C=CCc1ccccc1OC(=O)c1ccc(Br)cc1</smiles>

27, 2-allylpheny 4-bromobenzoate<smiles>C=CCc1cc(OC)c(OC)cc1O</smiles>

13, 2-allyl-4,5-dimethoxyphenol<smiles>COc1cc(C(O)C(=O)O)ccc1O</smiles>

10 , allylbenzene<smiles>C=CCc1ccc(C)cc1</smiles>

14, 4-allyltoluene<smiles>C/C=C/c1ccc(O)c(OC)c1</smiles>

18, eugenol

(4-allyl-2-methoxyphenol) 17, 4-hydroxy-3-methoxymandelic acid<smiles>C=CCc1cccc(OC)c1O</smiles>

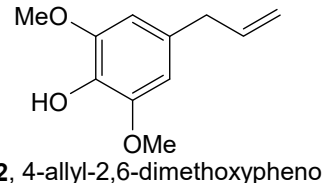

22, 4-allyl-2,6-dimethoxyphenol

21, 2-allyl-6-methoxypheno (o-eugenol)<smiles>C=CCc1ccc(OC)cc1</smiles>

24, estragole (methyl chavicol, 4-allylanisole)<smiles>C=CCc1ccccc1OS(C)(=O)=O</smiles>

28, 2-allylphenyl methanesulfonate<smiles>C=CCc1ccccc1OC(C)=O</smiles>

25, 2-allylphenyl acetate<smiles>C=CCc1ccccc1OC</smiles>

26, 2-allylanisole<smiles>C=CCc1ccccc1OC(=O)CCCCN</smiles>

29, 2-allylphenyl 5-azidopentanoat

Figure 1. The structures of compounds 1-29.

\section{Results and Discussion}

Aromatic compounds with different functional groups isolated from plants (1 and 2), fungi (3-5), and their commercially available analogs $(6-22,24)$ and some semisynthetic derivatives $(23,25-29)$ were investigated for potential attraction of male C. capitata. Five derivatives (25-29) (Figure 1) were 
semisynthesized from the commercially available 2-allylphenol (23, one of the active attractants of C. capitata in the initial bioassay; see the Materials and Methods section).

In particular, 2-allylphenol (23), by reaction with $\mathrm{Ac}_{2} \mathrm{O}$ and pyridine, was converted into the corresponding 1-O-acetylderivative (25). Its ${ }^{1} \mathrm{H}-\mathrm{NMR}$ spectrum differed from that of $\mathbf{2 3}$ for the presence of the typical singlet of the acetyl group at $\delta 2.32$ and was very similar to that previously reported Gresser et al. [24]. Further confirmation was given by an ESI-MS spectrum, which showed the protonated form $[\mathrm{M}+\mathrm{H}]^{+}$at $m / z 177$.

By reaction with an ethereal solution of diazomethane, 23 was converted into the corresponding methyl ether (allylanisole, 26). Its ${ }^{1} \mathrm{H}$ NMR spectrum differed from that of $\mathbf{2 3}$ for the significant presence of the singlet of methoxy group at $\delta 3.83$ and was very similar to that previously reported [25]. Furthermore, its ESI-MS showed the protonated form $[\mathrm{M}+\mathrm{H}]^{+}$at $m / z 149$.

2-Allylphenol (23), by reaction with 4-bromobenzoic acid, yielded its corresponding $p$-bromobenzoyl ester (27). Its ${ }^{1} \mathrm{H}-\mathrm{NMR}$ spectrum, compared with that of 23 , showed the typical signals pattern of the aromatic para-disubstituted protons, appearing as two doublets at $\delta 8.08$ and $7.69(\mathrm{~J}=8.7 \mathrm{~Hz})$. In addition, the ESI-MS spectrum showed the protonated form $[\mathrm{M}+\mathrm{H}]^{+}$of typical signals due to the presence of ${ }^{79} \mathrm{Br}$ and ${ }^{81} \mathrm{Br}$ isotopes peaks at $m / z 317[\mathrm{M}+\mathrm{H}]^{+}$and $319[\mathrm{M}+2+\mathrm{H}]^{+}$, respectively.

2-Allylphenol (23), by reaction with mesyl chloride in pyridine, afforded the corresponding mesyl ester (28). Its ${ }^{1} \mathrm{H}-\mathrm{NMR}$ spectrum was differed from 23 by the significant presence of the singlet of the methyl group at $\delta 3.20$ and was very similar to that previously reported by Lei et al. [26]. Its ESI-MS spectrum showed the protonated form $[\mathrm{M}+\mathrm{H}]^{+}$at $m / z 213$.

2-Allylphenol (23), by reaction with 5-azidopentanoic acid, afforded the 5-azido pentanoyl derivative (29). Its ${ }^{1} \mathrm{H}-\mathrm{NMR}$ spectrum differed from that of allylphenol for the presence of the signals of 5-azidopentanoyl residue, appearing at $3.32\left(\mathrm{t}, J=6.8 \mathrm{~Hz}, 2 \mathrm{H}, \mathrm{H}-5^{\prime \prime}\right), 3.21\left(\mathrm{~d}, J=6.6 \mathrm{~Hz}, 2 \mathrm{H}, \mathrm{H}-1^{\prime}\right)$, $2.64\left(\mathrm{t}, J=7.0 \mathrm{~Hz}, 2 \mathrm{H}, \mathrm{H}-2^{\prime \prime}\right), 1.91-1.84\left(\mathrm{~m}, 2 \mathrm{H}, \mathrm{H}-3^{\prime \prime}\right)$, and $1.79-1.74\left(\mathrm{~m}, 2 \mathrm{H}, \mathrm{H}-4^{\prime \prime}\right)$. Its ESI-MS spectrum showed the protonated form $[\mathrm{M}+\mathrm{H}]^{+}$at $m / z 260$.

All the natural, commercially available and synthetic compounds were assayed against $C$. capitata sterile males using short-range attraction bioassays and EAG analyses, as detailed in the Material and Methods section.

Two short-range bioassays were carried out. In Experiment 1, paired $t$-tests found that male response to compounds $7, \mathbf{9}, \mathbf{1 1}, \mathbf{1 3}, \mathbf{2 1}, \mathbf{2 3}, \mathbf{2 4}$, and 27 was higher than the response to the associated solvent control (Table 1). Response of flies was converted to Attraction Index for comparisons among these eight compounds. There was an effect of type of chemical on Attraction Index. $\left(F_{7,32}=16.69\right.$, $p<0.0001)$. The highest index was found with chemical $7(0.63 \pm 0.26)$, intermediate indexes with chemicals 24, 21, and $23(0.41 \pm 0.19,0.37 \pm 0.11$, and $0.28 \pm 0.08$, respectively), and the lowest indexes with chemicals $\mathbf{9}, \mathbf{1 1}, \mathbf{1 3}$, and 27 (ranging from $0.02 \pm 0.01$ to $0.08 \pm 0.06$ ).

These results demonstrated the importance of the functional groups and their position on the benzene ring. In particular, the side chain of 7 was the most important moiety to stimulate attraction of males in Experiment 1. The presence of the allyl group was also a critical factor, as evidenced by little or no attraction observed with compounds lacking this moiety, as in 1-6, 16, and 17. The same result was obtained when the allylic chain was modified by isomerization of the double bond, as in 9 and 18, or by the presence of a propyl residue, as in 19. However, other substitutions on the aromatic ring of allylbenzene (10) were needed to confer activity, as $\mathbf{1 0}$ elicited no response. When the number of substituents on the aromatic ring increased, those with three functional groups lost activity, as in 13, 15, and 22. Among compounds having two substituents, as in $\mathbf{2 0}$ and 21, only the latter, having a substituent ortho-located with respect to the allyl group, was active. Although methyl eugenol (20) is a male attractant for Bactrocera dorsalis (Diptera: Tephritidae) [27], male medflies showed poor response to compound 20. Among the ortho- and para-monosubstituted allyl benzenes, only $\mathbf{2 3}$ and $\mathbf{2 4}$ displayed activity while the others $(\mathbf{8}, \mathbf{1 1}, \mathbf{1 2}$, and $\mathbf{1 4})$ were inactive. This suggests that the efficacy was dependent upon the substituents and their volatility and fragrance. Furthermore, comparing the activity of 
the four esters $(25,27-29)$ and one ether of 23 with that of the parent compound, they were all less attractive. Thus, the presence of a free hydroxyl and the ortho-allyl group was important for the activity. It should also be noted that some of the compounds tested could be potential repellents; however, that determination would require bioassays with a different experimental design (e.g., a known attractant vs. a combination of attractant plus potential repellent). Further investigations are needed to assess potential repellent properties of compounds deemed non-attractive in this study.

Table 1. $\log P$ values and number (mean \pm std dev) of sterile male $C$. capitata attracted to compounds 1-29 presented in binary choice bioassays against control (Experiment 1).

\begin{tabular}{|c|c|c|}
\hline Compound & $\begin{array}{c}\log P \\
\text { Values }\end{array}$ & $\begin{array}{c}\text { Number } \\
\text { Responding }\end{array}$ \\
\hline phenyllactic acid (7) & 1.16 & $32.6 \pm 12.4$ * \\
\hline estragole (methyl chavicol, 4-allylanisole) (24) & 2.96 & $21.0 \pm 9.0 *$ \\
\hline 2-allyl-6-methoxyphenol (o-eugenol) (21) & 2.57 & $20.2 \pm 4.3^{*}$ \\
\hline 2-allylphenol (23) & 2.7 & $16.0 \pm 3.8^{*}$ \\
\hline 2-allylphenyl acetate (25) & 2.67 & $10.0 \pm 8.7$ \\
\hline 4-allyltoluene (14) & 3.57 & $8.8 \pm 8.3$ \\
\hline trans-anethole (9) & 2.91 & $6.0 \pm 2.3 *$ \\
\hline 2-allylphenyl 4-bromobenzoate (27) & 5.4 & $5.0 \pm 2.3 *$ \\
\hline 1-allyl-4-(trifluoromethyl)benzene (11) & 4.01 & $3.2 \pm 1.3 *$ \\
\hline 2-methoxy 4-propylphenol (19) & 2.84 & $3.0 \pm 3.3$ \\
\hline 2-allylphenyl methanesulfonate (28) & 1.99 & $3.0 \pm 0.7$ \\
\hline 4-hydroxybenzaldehyde (5) & 1.39 & $2.8 \pm 2.6$ \\
\hline 2-allylphenyl 5-azidopentanoate (29) & 3.65 & $2.6 \pm 1.3$ \\
\hline 1-allylbenzene (8) & 3.24 & $2.2 \pm 1.1$ \\
\hline 4-allylphenol (chavicol) (12) & 2.7 & $2.2 \pm 1.1$ \\
\hline tyrosol (3) & 1.35 & $2.0 \pm 1.6$ \\
\hline resorcinol (4) & 1.26 & $2.0 \pm 2.5$ \\
\hline 4-methylcatechol (6) & 1.74 & $1.6 \pm 2.1$ \\
\hline 2-allyl-4,5-dimethoxyphenol (13) & 2.44 & $1.6 \pm 0.5 *$ \\
\hline allylbenzene (10) & 3.09 & $1.4 \pm 0.9$ \\
\hline 4-allyl-1,2-dimethoxybenzene (= methyl eugenol) (20) & 2.83 & $1.4 \pm 0.5$ \\
\hline 3-hydroxy acetophenone (16) & 0.96 & $1.2 \pm 1.3$ \\
\hline 4-hydroxy-3-methoxymandelic acid (17) & 0.36 & $1.2 \pm 1.3$ \\
\hline 2-allylanisole (26) & 2.96 & $1.2 \pm 0.8$ \\
\hline 4-allyl-2,6-trimethoxybenzene (15) & 2.71 & $1.0 \pm 0.7$ \\
\hline eugenol (4-allyl-2-methoxyphenol) (18) & 2.52 & $0.8 \pm 0.8$ \\
\hline piceol (1) & 0.96 & $0.6 \pm 0.9$ \\
\hline 4-allyl-2,6-dimethoxyphenol (22) & 2.44 & $0.6 \pm 0.9$ \\
\hline acetovanillone (2) & 0.83 & $0.4 \pm 0.5$ \\
\hline
\end{tabular}

* Number of flies ( $n=5$ replicates, 50 flies per replicate) on treated paper was greater than number on solvent control (paired $t$-test, $p<0.05) .{ }^{£}$ as detailed in the Material and Methods section.

Lipophilicity, expressed as the logarithm of the octanol-water partition coefficient $(\log P)$, is often correlated with biological activity. $\log P$ values of a series of test chemicals often follow predictable trends in biological assays [28]. Compounds with lower $\log P$ values are classified as polar, while those with higher $\log P$ values are considered more lipophilic with better membrane permeability [29]. However, we did not observe any correlation between $\log P$ values for compounds 1-28 [30] and 29 [31] and male response in Experiment $1(r=0.03037, \mathrm{n}=29, p=0.8757)$ (Table 1).

When pairwise comparisons of the four most attractive compounds from Experiment 1 were tested in Experiment 2, there were clear choices among most chemicals (Table 2). More males were attracted to compound 21, and fewer males were attracted to compound $\mathbf{7}$ in all bioassays. Attraction to compounds $\mathbf{2 3}$ and $\mathbf{2 4}$ was intermediate, with no difference in attraction when $\mathbf{2 3}$ and $\mathbf{2 4}$ were tested together. Phenyllactic acid (7) has been isolated from cultures of Lactobacillus plantarum [32] and may function as a food-based attractant. Estragole (24) is more likely a kairomone, since it occurs in a 
variety of essential oil-bearing plants such as basil, tarragon, chervil, fennel, clary sage, anise, and rosemary [33], as well as in the leaves of various avocado cultivars [34], ripe apple [35] and citrus fruits [36].

Table 2. Number (mean \pm std dev) of male C. capitata attracted to each choice in pairwise comparisons of the top four compounds in Experiment 2 for 10 replicate tests with 50 flies per replicate.

\begin{tabular}{cccccccc}
\hline \multirow{2}{*}{$\begin{array}{c}\text { Compounds } \\
\text { Tested }\end{array}$} & \multicolumn{2}{l}{ Number Responding to Each Compound in Bioassay } & & & \\
\cline { 2 - 8 } & $\mathbf{7}$ & $\mathbf{2 1}$ & $\mathbf{2 3}$ & $\mathbf{2 4}$ & $\boldsymbol{t}$ & $\mathbf{d f}$ & $\boldsymbol{p}$ \\
\hline $\mathbf{7}$ versus $\mathbf{2 1}$ & $2.1 \pm 2.3$ & $17.3 \pm 4.4$ & & & 10.75 & 16.6 & $<0.0001$ \\
$\mathbf{7}$ versus 23 & $3.2 \pm 5.7$ & & $14.2 \pm 4.3$ & & 5.3 & 22 & $<0.0001$ \\
$\mathbf{7}$ versus 24 & $2.4 \pm 2.0$ & & & $16.1 \pm 5.6$ & 7.97 & 13.7 & $<0.0001$ \\
$\mathbf{2 1}$ versus $\mathbf{2 3}$ & & $17.8 \pm 6.0$ & $7.8 \pm 2.8$ & & 4.54 & 15.6 & 0.0001 \\
$\mathbf{2 1}$ versus 24 & & $17.1 \pm 5.7$ & & $7.8 \pm 5.4$ & 4.14 & 22 & 0.0004 \\
$\mathbf{2 3}$ versus $\mathbf{2 4}$ & & & $10.3 \pm 3.2$ & $10.4 \pm 4.9$ & 0.05 & 22 & 0.9809 \\
\hline
\end{tabular}

These results support that both the presence of the allyl residue, and substituents on the aromatic ring are key structural features that confer attraction of male C. capitata.

In EAG analyses (Figure 2), there were significant differences in mean olfactory response to test chemicals observed in all four groupings (Group 1: $F_{6,68}=185.02, p<0.001$; Group 2: $F_{6,68}=95.97$, $p<0.001$; Group 3: $F_{7,76}=375.321, p<0.001$; and Group 4: $\left.F_{6,68}=78.33, p<0.001\right)$. In general, strong EAG responses were elicited by compounds that were observed to be attractive in short range bioassays (indicated by black bars in Figure 2). Of the nine highest-ranked chemicals in Experiment 1 (Table 1), only compound 7 had a low amplitude depolarization peak (Figure 2, Group 3). This may have been due to differences in sample preparation between the bioassays and EAG analyses. The former used $10 \%$ dilutions in acetone, whereas the latter used chemicals in their neat form. With compound 7 , the neat material at $24{ }^{\circ} \mathrm{C}$ was in solid state, and the dry crystals may not have generated significant volatiles in the headspace of the EAG sample bottle. It is also possible that compound 7, when presented in bioassays, was detected by contact chemoreceptors on the tarsi rather than by antennal olfactory receptors.

In addition, there were two chemicals that elicited higher than expected EAG responses. Of the twenty low-ranked (i.e., non-attractive) chemicals from the behavioral assays (indicated by gray bars in Figure 2), all displayed weak EAG responses except for compounds $\mathbf{2 6}$ and 28, which produced relatively high amplitude EAG peaks (Figure 2, Group 3). Potential explanations for this observation are that these two chemicals may be (i) true attractants, but the insects are not at the proper physiological stage to respond appropriately (all test insects were sterile virgin males of the same age); (ii) synergistic attractants, not behaviorally active alone but increasing response when combined with primary attractants (e.g., putrescine, a synergist when combined with ammonia as a tephritid food-based attractant [37]; (iii) repellents, which would also be detected by antennal olfactory receptors (e.g., ammonia, a protein feeding cue attractive at low doses but repellent at high dose) [38]; or (iv) other biologically relevant compounds in the environment but unrelated to attraction behavior. 

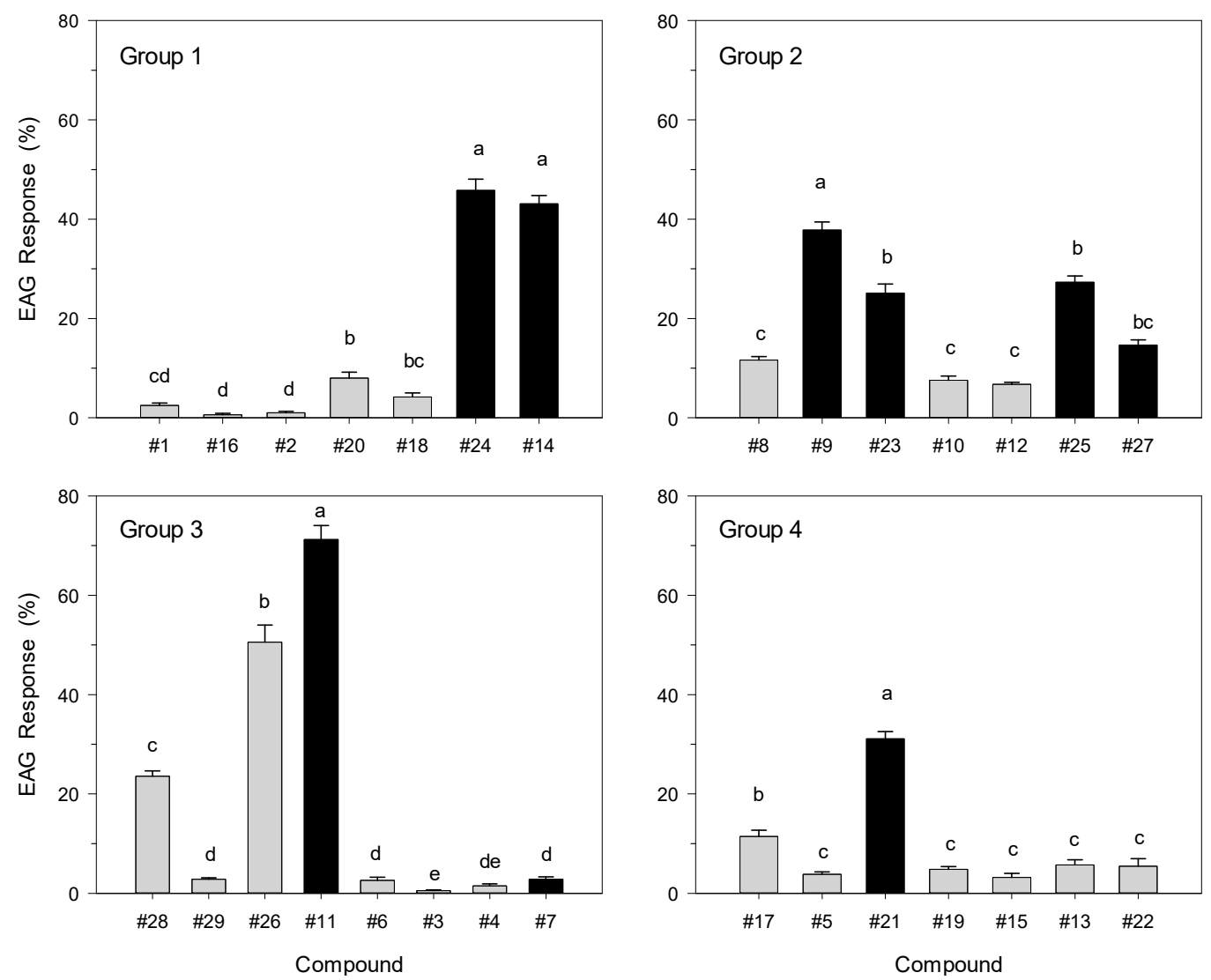

Figure 2. Mean ( $\pm \mathrm{SE}$ ) electroantennogram (EAG) responses of male $C$. capitata to $1 \mathrm{~mL}$ doses of saturated vapor from compounds 1-29 (neat material). Analyses were conducted using four groupings of randomly chosen samples; responses were measured from 10 replicate males per group. All EAG responses expressed as normalized percentages relative to the standard reference sample (tea tree essential oil, $1 \mathrm{~mL}$ saturated vapor). Black bars indicate compounds found attractive in short-range bioassays; gray bars indicate non-attractive compounds. Within each group comparison, bars topped with the same letter are not significantly different (Tukey mean separation, $p<0.05$ ).

\section{Materials and Methods}

\subsection{General Experimental Procedures}

${ }^{1} \mathrm{H}$ NMR spectra were recorded at 500 and $400 \mathrm{MHz}$ in $\mathrm{CDCl}_{3}$ on Varian (Varian, Palo Alto, CA, USA) and Bruker (Bruker, Karlsruhe, Germany) spectrometers. The same solvent was used as internal standard. Liquid chromatography-mass spectrometry (LC-MS) analysis was performed on an Agilent HPLC 1100 VL instrument (Agilent Technologies, Milan, Italy) equipped with an electrospray ionization source (positive ion mode, ESI+). An Eclipse XBD-C18 column $(150 \mathrm{~mm} \times 4.60 \mathrm{~mm}, 5 \mu \mathrm{m})$ was used, adopting $0.1 \%$ formic acid: $\mathrm{MeOH}$ (35:65) as the eluant (flow rate: $0.4 \mathrm{~mL} / \mathrm{min}$ ). Analytical and preparative TLC were performed on silica gel (Kieselgel $60, \mathrm{~F}_{254}, 0.25$ and $0.5 \mathrm{~mm}$ respectively) plates. The spots were visualized by exposure to UV radiation $(253 \mathrm{~nm})$ or iodine vapour or by spraying first with $10 \% \mathrm{H}_{2} \mathrm{SO}_{4}$ in $\mathrm{MeOH}$ and then with $\%$ phosphomolybdic acid in $\mathrm{EtOH}$, followed by heating at $110^{\circ} \mathrm{C}$ for $10 \mathrm{~min}$. Column chromatography was performed using silica gel (Merck, Kieselgel 60, 0.06-0.200 mm, KgaA, Darmstadt, Germany). Log $P$ values were computed by using ChemDraw 18.0 Ultra (1-28) [30] and ChemAxon 19.10 (29) [31].

\subsection{Natural and Synthetic Compounds}

The compounds used for the study (Figure 1) are natural and synthetic aromatic derivatives with different functional groups. In particular, piceol (1) and acetovanillone (2) were purified from 
the organic extract of Crinum buphanoides bulbs, a native South African Amaryllidaceae plant [21]. Tyrosol (3) and resorcinol (4) were isolated from the culture filtrate of the fungus Dothiorella vidmadera, a pathogen involved in the Botryosphaeria dieback of grapevine [22]. 4-Hydroxybenzaldehyde (5) was isolated from the solid cheatgrass (Bromus tectorum) culture of a Fusarium strain belonging to the F. tricinctum species complex [23]. Compound 12 (Cas\# 501-92-8) was purchased from Parkway Scientific (New York, NY, USA), 13 (Cas\# 59893-87-7) was purchased from Enamine Ltd. (Monmouth Junction, NJ, USA), and 15 (Cas\# 487-11-6) was purchased from BOC Sciences (Shirley, NY, USA). All other compounds (6 (Cas\# 452-86-8), 7 (Cas\# 20312-36-1), 8 (Cas\# 1737-16-2), 9 (Cas\# 4180-23-8), 10 (Cas\# 300-57-2), 11 (Cas\# 1813-97-4), 14 (Cas\# 3333-13-9), 16 (Cas\# 121-71-1), 17 (Cas\# 55-10-7), 18 (Cas\# 97-53-0), 19 (Cas\# 2785-87-7), 20 (Cas\# 93-15-2), 21 (Cas\# 579-60-2), 22 (Cas\# 6627-88-9), 23 (Cas\# 1745-81-9), and 24 (Cas\# 140-64-0) were supplied from Sigma-Aldrich Ltd. (St. Louis, MO, USA).

Synthesis of 2-Allylphenol Derivatives 25-29

2-allylphenil acetate (25). 2-allylphenol $(23,120 \mu \mathrm{L})$, dissolved in pyridine $(50 \mu \mathrm{L})$, was converted in its corresponding acetyl ester (25) by acetylation with $\mathrm{Ac}_{2} \mathrm{O}(50 \mu \mathrm{L})$. The reaction was carried out under stirring for 12 hours at room temperature. It was stopped with $\mathrm{MeOH}$, and the azeotrope formed by addition of $\mathrm{C}_{6} \mathrm{H}_{6}$ was evaporated under $\mathrm{N}_{2}$ stream. The residue $(125.2 \mathrm{~g})$ was then purified by column chromatography (CC) on silica gel eluted with $n$-hexane:EtOAc (9:1) yielding 25 (119.3 $\mathrm{mg}$ ) as an amorphous oil. Its ${ }^{1} \mathrm{H}$ NMR data were very similar to those previously reported by Gresser et al. [24]; ESI+/MS: $m / z 177[\mathrm{M}+\mathrm{H}]^{+}$.

2-allylanisole (26). An ethereal solution of $\mathrm{CH}_{2} \mathrm{~N}_{2}$ was added to a solution of 2-allylphenol (23, $120 \mu \mathrm{L})$ in $\mathrm{MeOH}(120 \mu \mathrm{L})$ to obtain a persistent yellow color. The reaction was carried out at room temperature under stirring and was stopped after $24 \mathrm{~h}$ by evaporation under an $\mathrm{N}_{2}$ stream. The crude residue (130.1 mg) was purified by CC, using $n$-hexane:EtOAc (9:1) as eluent, to give $100 \mathrm{mg}$ of 2-allylanisole (23) as a homogeneous compound. Its ${ }^{1} \mathrm{H}$ NMR data were very similar to those already reported in literature [25]; ESI+/MS: $m / z 149[\mathrm{M}+\mathrm{H}]^{+}$.

2-allylphenyl-4-bromobenzoate (27). To 2-allylphenol (23, $180 \mu \mathrm{L})$, dissolved in anhydrous MeCN $(600 \mu \mathrm{L}), \mathrm{DMAP}(120.0 \mathrm{mg})$ and $p$-bromobenzoilchloride $(120.0 \mathrm{mg})$ were added. The reaction mixture was left under stirring for $24 \mathrm{~h}$. It was then quenched with a $1 \mathrm{~N} \mathrm{NaHCO}_{3}$, extracted with EtOAc and washed with $\mathrm{H}_{2} \mathrm{O}$. The residue obtained by evaporation $(244.6 \mathrm{mg})$ was then purified by CC eluted with $n$-hexane:acetone (9:1), affording the $p$-bromobenzoyl ester of 2-allylphenol (27, $102.2 \mathrm{mg})$. Derivative 27 had ${ }^{1} \mathrm{H}$ NMR (400 MHz, $\left.\mathrm{CDCl}_{3}, \delta, \mathrm{ppm}\right) ; \delta 8.08\left(\mathrm{~d}, J=8.7 \mathrm{~Hz}, 2 \mathrm{H}, \mathrm{H}-2^{\prime \prime}\right.$ and H-6"), 7.69 $\left(\mathrm{d}, J=8.7 \mathrm{~Hz}, 2 \mathrm{H}, \mathrm{H}-3^{\prime \prime}\right.$ and H-5"), $7.32(\mathrm{~m}, 2 \mathrm{H}, \mathrm{H}-5$ and H-3), $7.26(\mathrm{td}, J=7.3$ and $2.5 \mathrm{~Hz}, 1 \mathrm{H}, \mathrm{H}-4), 7.18$ (br d, $J=7.3 \mathrm{~Hz}, 1 \mathrm{H}, \mathrm{H}-6), 5.93\left(\mathrm{ddt}, J=17.1,10.6\right.$ and $\left.6.6 \mathrm{~Hz}, 1 \mathrm{H}, \mathrm{H}-2^{\prime}\right), 5.05(\mathrm{dd}, J=10.6$ and $2.9 \mathrm{~Hz}$, $\left.1 \mathrm{H}, \mathrm{H}-3^{\prime} \mathrm{A}\right), 5.02\left(\mathrm{dd}, J=17.1\right.$ and $\left.2.9 \mathrm{~Hz}, 1 \mathrm{H}, \mathrm{H}-3^{\prime} \mathrm{B}\right)$, and $3.21\left(\mathrm{~d}, J=6.6 \mathrm{~Hz}, 2 \mathrm{H}, \mathrm{H}_{2}-1^{\prime}\right)$; and ESI+/MS: $m / z 319[\mathrm{M}+2+\mathrm{H}]^{+}, 317[\mathrm{M}+\mathrm{H}]^{+}$.

Mesyl ester of 2-allylphenol (28). Two hundred and fifty $\mu \mathrm{L}$ of mesyl chloride were added to a solution of 2-allylphenol $(23,60 \mu \mathrm{L})$ in $\mathrm{CH}_{2} \mathrm{Cl}_{2}(300 \mu \mathrm{L})$ together with $60 \mu \mathrm{L}$ of pyridine. The reaction mixture was kept overnight and then quenched with a $1 \mathrm{~N}$ solution of $\mathrm{HCO}_{3}{ }^{-}$. The mixture was then extracted with EtOAc, and the resulting organic extract $(63.1 \mathrm{mg})$ was purified by preparative TLC eluted with $\mathrm{CHCl}_{3}$, affording the methyl ester derivative of 2-allylphenol (28, 52.6 mg). ${ }^{1} \mathrm{H}$ NMR data of 28 were very similar to those previously reported by Lei et al. [26]; ESI+/MS: $m / z 213[\mathrm{M}+\mathrm{H}]^{+}$.

Azidopentanoyl ester of 2-allylphenol (29). 2-allylphenol (23, $120.0 \mu \mathrm{L})$ dissolved in anhydrous $\mathrm{CH}_{2} \mathrm{Cl}_{2}(600 \mu \mathrm{L})$ and pyridine $(120 \mu \mathrm{L})$, and DCC ( $N, N$-dicyclohexylcarbodiimide) $(40 \mathrm{mg})$ and 5 -azidopentanoic acid $(120 \mu \mathrm{L})$ were added. The reaction was left at room temperature for 4 days. The reaction was stopped by evaporation under $\mathrm{N}_{2}$. The residual oil $(178.2 \mathrm{mg})$ was then purified by CC eluted with $n$-hexane:acetone (9:1), affording 5-azidopentanoyl ester of 2-allylphenol (29, $43.8 \mathrm{mg})$. Derivative 29 had ${ }^{1} \mathrm{H}$ NMR (400 MHz, $\left.\mathrm{CDCl}_{3}, \delta, \mathrm{ppm}\right) ; \delta 7.32$ (m, 2H, H-5 and H-3), 7.26 (td, $J=7.3$ and $2.5 \mathrm{~Hz}, 1 \mathrm{H}, \mathrm{H}-4), 7.18(\mathrm{br} \mathrm{d}, J=7.3 \mathrm{~Hz}, 1 \mathrm{H}, \mathrm{H}-6), 5.92\left(\mathrm{ddt}, J=17.1,10.6\right.$ and $\left.6.6 \mathrm{~Hz}, 1 \mathrm{H}, \mathrm{H}-2^{\prime}\right)$, $5.05\left(\mathrm{dd}, J=10.6\right.$ and $\left.2.9 \mathrm{~Hz}, 1 \mathrm{H}, \mathrm{H}-3^{\prime} \mathrm{A}\right), 5.02\left(\mathrm{dd}, J=17.1\right.$ and $\left.2.9 \mathrm{~Hz}, 1 \mathrm{H}, \mathrm{H}-3^{\prime} \mathrm{B}\right), 3.32(\mathrm{t}, J=6.8 \mathrm{~Hz}$, 
$\left.2 \mathrm{H}, \mathrm{H}-5^{\prime \prime}\right), 3.21\left(\mathrm{~d}, J=6.6 \mathrm{~Hz}, 2 \mathrm{H}, \mathrm{H}-1^{\prime}\right), 2.64\left(\mathrm{t}, J=7.0 \mathrm{~Hz}, 2 \mathrm{H}, \mathrm{H}-2^{\prime \prime}\right), 1.91-1.84\left(\mathrm{~m}, 2 \mathrm{H}, \mathrm{H}-3^{\prime \prime}\right)$, and 1.79-1.74 (m, 2H, H-4").; ESI+/MS: $m / z 260[\mathrm{M}+\mathrm{H}]^{+}$.

\subsection{Insects}

Sterile male C. capitata were obtained from the Programa Moscamed mass rearing facility (El Pino, Guatemala), where they were irradiated as pupae $2 \mathrm{~d}$ prior to emergence with $95 \mathrm{~Gy}$ of gamma radiation from a Co60 source. These are the temperature-sensitive lethal strain flies [39] that are used for the preventative release program [40] in Florida. Thus, only males were obtained, and only virgin males were used for testing. Irradiated pupae were shipped initially to the USDA-APHIS Medfly Project (Sarasota, FL, USA) and then to the USDA-ARS Subtropical Horticulture Research Station in Miami, FL. Holding conditions at Miami consisted of a 12/12 h L/D photoperiod, $25 \pm 2{ }^{\circ} \mathrm{C}$, and $75 \pm 5 \%$ RH. Pupae were placed in collapsible cages $(30.5 \times 30.5 \times 30.5 \mathrm{~cm})$. After eclosion, adult flies were provided with water ( $2 \%$ agar blocks) and food (3:1 mixture of cane sugar and yeast hydrolysate). Flies used for all studies were 5 to $10 \mathrm{~d}$-old, sexually mature sterile virgin males. Only sterile flies were available for use in this research because there are no wild populations in Florida. Previous research, however, has found that response of sterile males to semiochemicals is similar to response of wild males (e.g., Reference [15]).

\subsection{Short-Range Bioassays}

Small cage bioassays were used to quantify the short-range attraction of sterile male $C$. capitata using a modified version of the binary choice tests [41]. All observations were carried out at room temperature as described above in small collapsible cages $(20.3 \times 20.3 \times 20.3 \mathrm{~cm})$ into which 50 flies were introduced $1 \mathrm{~h}$ prior to the start of each experiment. Tests were initiated by introducing two Petri dishes ( $53 \mathrm{~mm}$ diameter and $12 \mathrm{~mm}$ height) with substrates positioned symmetrically ( $37 \mathrm{~mm}$ apart). After $30 \mathrm{~min}$, the number of flies at each dish was recorded. Experiment 1 compared the response to each individual chemical $(10 \mu \mathrm{L}$ of a $10 \%$ dilution in acetone) with the response to a paired solvent control (10 $\mu \mathrm{L}$ acetone). Test substrate or control was added to the center of a filter paper disk (Whatman \#1, $3.5 \mathrm{~cm}$ diam). The filter paper disk was air-dried briefly to allow the solvent to evaporate and was placed into the middle of a Petri dish. Bioassays were replicated five times, and the position of substrates reversed between replicates. Flies and Petri dishes were used only once, and cages were washed with acetone between experiments to eliminate potential residual chemicals.

Pairwise comparisons of the chemicals that elicited the highest response in the initial tests were then conducted in Experiment 2 (compounds 7, 21, 23, and 24). The response to each individual chemical ( $10 \mu \mathrm{L}$ of a $10 \%$ dilution in acetone) was compared with the response to each other selected chemicals in this two-choice test bioassay with all possible combinations tested ( 7 vs. 21,7 vs. 23,7 vs. 24,21 vs. 23,21 vs. 24,23 vs. 24 ). There were ten replicates of the pairwise comparisons, with each pair tested in separate cages at the same time.

\subsection{Electroantennography (EAG) Analysis}

Peripheral olfactory responses were recorded from antennae of male C. capitata using a Syntech EAG system (Syntech Original Research Instruments, Hilversum, Netherlands) and methods developed by Kendra et al. [37,38,42]. Test substrates consisted of the 29 compounds, each 20 mg neat material. The standard reference sample (positive control) was tea tree oil, $20 \mathrm{mg}$ (Essential Oil India-SAT Group, Kannauj, India), shown previously to elicit strong EAG responses in male medflies [15]. Each substrate was placed into a separate $250 \mathrm{~mL}$ hermetic glass bottle equipped with a lid containing a short thru-hull port (Swagelok, Solon, OH, USA) and silicone septum (Alltech, Deerfield, IL, USA). Sample bottles were sealed and equilibrated overnight at $24^{\circ} \mathrm{C}$ to allow for headspace saturation with volatiles.

Freshly dissected antennal preparations (whole head mounts) were secured between electrodes using salt-free conductive gel (Spectra 360, Parker Laboratories, Fairfield, NJ, USA) and placed under a stream of humidified air, purified with activated charcoal granules, at a flow rate of $400 \mathrm{~mL} / \mathrm{min}$. 
Using gas-tight syringes (SGE Analytical Science, Victoria, Australia), samples of saturated vapor were withdrawn from the test bottles, injected into the airstream, and presented to the antennae. In each recording session, samples (fixed $1 \mathrm{~mL}$ doses) were delivered in the following order: the tea tree standard, test chemicals in random order, a clean air injection (negative control), and a final standard injection. There was a 2-min interval (clean air flush) between injections to prevent antennal adaptation (diminished EAG response resulting from repeated exposure to chemical stimuli). Due to the large number of test chemicals, EAG analyses were conducted using four groupings; each group compared olfactory responses to seven or eight chemicals, randomly chosen, and responses were measured from ten replicate females.

EAG responses to test substrates were measured initially in millivolts (peak height of depolarization) and then normalized to percentages relative to the EAG response obtained with the reference sample. Normalization corrects for time-dependent variability (gradual decline) in antennal performance and allows for comparison of relative EAG responses obtained with different substrates [37,43-45] and with different cohorts of insects [37,38]. Finally, any response recorded with the negative control was subtracted from the normalized test responses to correct for "pressure shock" caused by injection volume. All statistical analyses were performed using the corrected normalized EAG values.

\subsection{Statistical Analysis}

Pair $t$-tests were used to test for differences in number of males attracted to each choice in the binary choice tests in Experiments 1 and 2 (Proc TTEST; SAS Institute, 2016) [46]. Male response was converted to Attraction Index (number attracted to the compound minus number attracted to the control divided by total number of males tested) [47] to compare the eight compounds that attracted more males than the paired control in Experiment 1. One-way ANOVA and Tukey's mean separation tests were used to determine effect of chemical on Attraction Index in Experiment 1 and on olfactory responses in EAG analyses. When necessary, data were transformed prior to ANOVA to satisfy conditions of equal variance [48]; non-transformed means \pm standard deviations are presented.

\section{Conclusions}

In an effort to find effective new attractants for C. capitata, we investigated 29 structurally related aromatic compounds in short range bioassays and EAG analyses. The combined results identified phenyllactic acid (7), estragole (24), o-eugenol (21), and 2-allylphenol (23) as promising candidates for sexually mature males. Of these four compounds, o-eugenol (21) was observed to be the most attractive in binary choice tests. The presence of the allyl residue and substituents on the aromatic ring appear to be key structural features that confer attraction to these compounds. This study provides insight into the attractiveness of structural variants of aromatic compounds with various substituent groups to male C. capitata. Another promising approach could be the synthesis of estragole analogs with allyl groups at different sites on the aromatic ring. In addition, further studies are needed to evaluate these compounds, alone and in combination, to determine their efficacy in the field.

Author Contributions: All the authors contributed in the design of the study, the analysis of the data, and writing of the manuscript. N.T. performed the conceptualization and wrote a draft of the manuscript; N.T., M.M., P.N., A.C., and A.N. conceived and designed the chemical experiments; N.T., N.D.E., and J.N. planned and performed the bioassays; P.E.K. planned and performed the EAG analyses; N.D.E. and P.E.K. performed the statistical analysis; N.T., P.E.K., and A.E. finalized the draft and revised the manuscript. All authors read and approved the final manuscript.

Funding: This research was funded by Programme STAR 2017, financially supported by UniNA and Compagnia di San Paolo grant number E62F16001250003.

Acknowledgments: The technical assistances of Micah Gill, Wayne Montgomery, Monica Blanco, Amanda Perez-Castro, Sean Brown, and Teresa Narvaez of USDA-ARS-SHRS are greatly appreciated. The authors wish to thank Elena Schnell of USDA-ARS-SHRS for the chemical orders and for preparing samples for the bioassays. The authors thank Antonio Evidente, associated with "Istituto di Chimica Biomolecolare del CNR", Pozzuoli, Italy. 
We also thank the journal editors and referees for critical reviews of an earlier version of this manuscript. The mention of a trademark or proprietary product does not constitute a guarantee or warranty of the product by the U.S. Department of Agriculture, Agricultural Research Service and does not imply its approval to the exclusion of other products that may also be suitable.

Conflicts of Interest: The authors declare no conflict of interest.

\section{References}

1. Kendra, P.E.; Roda, A.L.; Montgomery, W.S.; Schnell, E.Q.; Niogret, J.; Epsky, N.D.; Heath, R.R. Gas chromatography for detection of citrus infestation by fruit fly larvae (Diptera: Tephritidae). Postharvest Biol. Technol. 2011, 59, 143-149. [CrossRef]

2. Katsoyannos, B.I.; Heath, R.R.; Papadopoulos, N.T.; Epsky, N.D.; Hendrichs, J. Field evaluation of Mediterranean fruit fly (Diptera: Tephritidae) female selective attractants for use in monitoring programs. J. Chem. Ecol. 1999, 92, 583-589. [CrossRef]

3. Midgarden, D.; Ovalle, O.; Epsky, N.D.; Puche, H.; Kendra, P.E.; Rendon, P.; Heath, R.R. Capture of Mediterranean fruit flies (Diptera: Tephritidae) in dry traps baited with food-based attractant and Jackson traps baited with trimedlure during sterile male release in Guatemala. J. Econ. Entomol. 2004, 97, 2137-2143. [CrossRef]

4. Puche, H.; Midgarden, D.G.; Ovalle, O.; Kendra, P.E.; Epsky, N.D.; Rendon, P.; Heath, R.R. Effect of elevation and host availability on distribution of sterile and wild Mediterranean fruit flies (Diptera: Tephritidae). Fla. Entomol. 2005, 88, 83-90. [CrossRef]

5. Papadopoulos, N.T. Fruit fly invasion: Historical, biological, economical aspects and management. In Trapping and the Detection, Control, and Regulation of Tephritid Fruit Flies, 1st ed.; Shelly, T., Epsky, N.D., Jang, E.B., Reyes-Flores, J., Vargas, R., Eds.; Springer Publishing: New York, NY, USA, 2014; pp. $219-252$.

6. Szyniszewska, A.M.; Leppla, N.C.; Huang, Z.; Tatem, A.J. Analysis of seasonal risk for importation of the Mediterranean Fruit Fly, Ceratitis capitata (Diptera:Tephritidae), via air passenger traffic arriving in Florida and California. J. Econ. Entomol. 2016, 109, 2317-2328. [CrossRef] [PubMed]

7. FAO-IAEA. Eradication of the Mediterranean Fruit Fly from the Dominican Republic Using Nuclear Technology. Available online: http://www.fao.org/3/ca0148en/CA0148EN.pdf (accessed on 13 May 2019).

8. Yiridoe, E.K.; Bonti-Ankomah, S.; Ralph, C.; Martin, R.C. Comparison of consumer perceptions and preference toward organic versus conventionally produced foods: A review and update of the literature. Renew. Agric. Food Syst. 2005, 20, 193-205. [CrossRef]

9. Johnson, J.A.; Walse, S.S.; Gerik, J.S. Status of alternatives for methyl bromide in the United States. Outlook Pest Manag. 2012, 23, 53-58. [CrossRef]

10. Shelly, T.E.; Whittier, T.S.; Villalobos, E.M. Trimedlure affects mating success and mate attraction in male Mediterranean fruit flies. Entomol. Exp. Appl. 1996, 78, 181-185. [CrossRef]

11. Jang, E.B.; Raw, A.S.; Carvalho, L.A. Field attraction of Mediterranean fruit fly, Ceratitis capitata (Wiedemann) to synthetic stereoselective enantiomers of the ceralure B1 isomer. J. Chem. Ecol. 2001, 27, 235-242. [CrossRef]

12. Quilici, S.; Atiama-Nurbel, T.; Brevault, T. Plant odors as fruit fly attractants. In Trapping and the Detection, Control, and Regulation of Tephritid Fruit Flies, 1st ed.; Shelly, T., Epsky, N.D., Jang, E.B., Reyes-Flores, J., Vargas, R., Eds.; Springer Publishing: New York, NY, USA, 2014; pp. 119-144.

13. Simanton, W.A. Studies of Mediterranean fruit fly lures in Florida. J. Econ. Entomol. 1958, 51, 679-682. [CrossRef]

14. Niogret, J.; Montgomery, W.S.; Kendra, P.E.; Heath, R.R.; Epsky, N.D. Attraction and electroantennogram responses of Male Mediterranean fruit fly to volatile chemicals from Persea, Litchi and Ficus wood. J. Chem. Ecol. 2011, 37, 483-491. [CrossRef] [PubMed]

15. Niogret, J.; Gill, M.A.; Espinoza, H.R.; Kendra, P.E.; Epsky, N.D. Attraction and electroantennogram responses of male Mediterranean fruit fly (Diptera: Tephritidae) to six plant essential oils. J. Entomol. Zool. Stud. 2017, 5, 958-964.

16. Epsky, N.F.; Niogret, J. Short range attraction of Ceratitis capitata (Diptera: Tephritidae) sterile males to six commercially available plant essential oils. Nat. Volatiles Essent. Oils 2017, 4, 1-7.

17. Dewick, P.M. Medicinal Natural Products: A Biosynthetic Approach; John Wiley \& Sons: West Sussex, UK, 2002. 
18. Martins, S.; Mussatto, S.I.; Martínez-Avila, G.; Montañez-Saenz, J.; Aguilar, C.N.; Teixeira, J.A. Bioactive phenolic compounds: Production and extraction by solid-state fermentation. A review. Biotechnol. Adv. 2011, 29, 365-373. [CrossRef] [PubMed]

19. Cimmino, A.; Masi, M.; Evidente, M.; Superchi, S.; Evidente, A. Amaryllidaceae alkaloids: Absolute configuration and biological activity. Chirality 2017, 29, 486-499. [CrossRef] [PubMed]

20. Masi, M.; Mubaiwa, B.; Mabank, T.; Karakoyun, C.; Cimmino, A.; Van Otterlo, W.A.L.; Green, I.R.; Evidente, A. Alkaloids isolated from indigenous South African Amaryllidaceae: Crinum buphanoides (Welw. ex Baker), Crinum graminicola (I. Verd.), Cyrtanthus mackenii (Hook. f) and Brunsvigia grandiflora (Lindl). S. Afr. J. Bot. 2018, 118, 88-191. [CrossRef]

21. Masi, M.; Mubaiwa, B.; Cimmino, A.; Van Otterlo, W.A.L.; Green, I.R.; Evidente, A. First isolation of acetovanillone and piceol from Crinum buphanoides and Crinum graminicola (I. Verd.) Amaryllidaceae. S. Afr. J. Bot. 2018, 114, 37-39. [CrossRef]

22. Reveglia, P.; Savocchia, S.; Billones-Baaijens, R.; Cimmino, A.; Evidente, A. Isolation of phytotoxic phenols and characterization of a new 5-hydroxymethyl-2-isopropoxyphenol from Dothiorella vidmadera, a causal agent of grapevine trunk disease. J. Agric. Food Chem. 2018, 66, 1760-1764. [CrossRef] [PubMed]

23. Masi, M.; Meyer, S.; Pescitelli, G.; Cimmino, A.; Clement, S.; Peacock, B.; Evidente, A. Phytotoxic activity against Bromus tectorum for secondary metabolites of a seed-pathogenic Fusarium strain belonging to the $F$. tricinctum species complex. Nat. Prod. Res. 2017, 31, 2768-2777. [CrossRef]

24. Gresser, M.J.; Wales, S.M.; Keller, P.A. The attempted stereoselective synthesis of chiral 2, 2'-biindoline. Tetrahedron 2010, 66, 6965-6976. [CrossRef]

25. Denmark, S.E.; Werner, N.S. Cross-coupling of aromatic bromides with allylic silanolate salts. J. Am. Chem. Soc. 2008, 130, 16382-16393. [CrossRef]

26. Lei, X.; Jalla, A.; Shama, M.A.A.; Stafford, J.M.; Cao, B. Chromatography-free and eco-friendly synthesis of aryl tosylates and mesylates. Synthesis 2015, 47, 2578-2585. [CrossRef]

27. Shelly, T.E. Fruit fly alphabets. In Trapping and the Detection, Control, and Regulation of Tephritid Fruit Flies, 1st ed.; Shelly, T., Epsky, N.D., Jang, E.B., Reyes-Flores, J., Vargas, R., Eds.; Springer Publishing: New York, NY, USA, 2014; pp. 3-11.

28. Baker, E.A.; Hayes, A.L.; Butler, R.C. Physicochemical properties of agrochemicals: Their effects on foliar penetration. Pest Manag. Sci. 1992, 34, 167-182. [CrossRef]

29. Jewess, P.J.; Chamberlain, K.; Boogaard, A.B.; Devonshire, A.L.; Khambay, B.P. Insecticidal 2-hydroxy-3alkyl-1,4-naphthoquinones: Correlation of inhibition of ubiquinol cytochrome c oxidoreductase (complex III) with insecticidal activity. Pest Manag. Sci. 2002, 58, 243-247. [CrossRef] [PubMed]

30. ChemDraw Ultra version 18.0. Available online: https://www.perkinelmer.com/category/chemdraw (accessed on 11 May 2019).

31. ChemAxon version 19.10. Available online: https://chemaxon.com/products/marvin (accessed on 11 May 2019).

32. Lavermicocca, P.; Valerio, F.; Visconti, A. Antifungal activity of phenyllactic acid against molds isolated from bakery products. Appl. Environ. Microbiol. 2003, 69, 634-640. [CrossRef] [PubMed]

33. Sell, C. Chemistry of essential oils. In Handbook of Essential Oils: Science, Technology, and Applications, 2nd ed.; Baser, K.H.C., Buchbauer, G., Eds.; CRC Press: Boca Raton, FL, USA, 2010; pp. 121-150.

34. King, J.R.; Knight, R.J. Occurrence and assay of estragole in the leaves of various avocado cultivars. J. Agric. Food Chem. 1987, 35, 842-844. [CrossRef]

35. Yauk, Y.K.; Chagne, D.; Tomes, S.; Matich, A.J.; Wang, M.Y.; Chen, X.; Maddumage, R.; Hunt, M.B.; Rowan, D.D.; Atkinson, R.G. The O-methyltransferase gene MdoOMT1 is required for biosynthesis of methylated phenylpropenes in ripe apple fruit. Plant J. 2015, 82, 937-950. [CrossRef] [PubMed]

36. Abbate, L.; Tusa, N.; Fatta Del Bosco, S.; Tonia Strano, T.; Renda, A.; Ruberto, G. Genetic improvement of Citrus fruits: New somatic hybrids from Citrus sinensis (L.) Osb. and Citrus limon (L.) Burm. F. Food Res. Int. 2012, 48, 284-290. [CrossRef]

37. Kendra, P.E.; Epsky, N.D.; Montgomery, W.S.; Heath, R.R. Response of Anastrepha suspensa (Diptera: Tephritidae) to terminal diamines in a food-based synthetic attractant. Environ. Entomol. 2008, 37, 1119-1125. [CrossRef] 
38. Kendra, P.E.; Vázquez, A.; Epsky, N.D.; Heath, R.R. Ammonia and carbon dioxide: Quantitation and electroantennogram responses of Caribbean fruit fly, Anastrepha suspensa (Diptera: Tephritidae). Environ. Entomol. 2005, 34, 569-575. [CrossRef]

39. Franz, G. Genetic sexing strains amenable to large scale rearing as required for the sterile insect technique. In the Sterile Insect Technique: Principles and Practice in Area-Wide Integrated Pest Management; Dyck, V.A., Hendrichs, J., Robinson, A.S., Eds.; Springer: Dordrecht, The Netherlands, 2005; pp. 427-452.

40. Dowell, R.V.; Siddiqui, I.A.; Meyer, F.; Spaugy, E.L. Mediterranean fruit fly preventative release programme in southern California. In Area-Wide Control of Fruit Flies and Other Insect Pests; Tan, K.H., Ed.; Penerbit Universiti Sains Malaysia: Pulau Pinang, Malaysia, 2000; pp. 369-375.

41. McInnis, D.O.; Warthen, J.D., Jr. Mediterranean fruit fly (Diptera: Tephritidae): Laboratory bioassay for attraction of males to leaf or stem substances from Ficus and Litchi. J. Econ. Entomol. 1988, 81, 1637-1640. [CrossRef]

42. Kendra, P.E.; Montgomery, W.S.; Mateo, D.M.; Puche, H.; Epsky, N.D.; Heath, R.R. Effect of age on EAG response and attraction of female Anastrepha suspensa (Diptera: Tephritidae) to ammonia and carbon dioxide. Environ. Entomol. 2005, 34, 584-590. [CrossRef]

43. Kendra, P.E.; Montgomery, W.S.; Niogret, J.; Pruett, G.E.; Mayfield, A.E., III; MacKenzie, M.; Deyrup, M.A.; Bauchan, G.R.; Ploetz, R.C.; Epsky, N.D. North American Lauraceae: Terpenoid emissions, relative attraction, and boring preferences of redbay ambrosia beetle, Xyleborus glabratus (Coleoptera: Curculionidae: Scolytinae). PLoS ONE 2014, 9, e102086. [CrossRef] [PubMed]

44. Kendra, P.E.; Montgomery, W.S.; Niogret, J.; Schnell, E.Q.; Deyrup, M.A.; Epsky, N.D. Evaluation of seven essential oils identifies cubeb oil as most effective attractant for detection of Xyleborus glabratus. J. Pest Sci. 2014, 87, 681-689. [CrossRef]

45. Kendra, P.E.; Owens, D.; Montgomery, W.S.; Narvaez, T.I.; Bauchan, G.R.; Schnell, E.Q.; Tabanca, N.; Carrillo, D. $\alpha$-Copaene is an attractant, synergistic with quercivorol, for improved detection of Euwallacea nr. fornicatus (Coleoptera: Curculionidae: Scolytinae). PLoS ONE 2017, 12, e179416.

46. SAS Institute. SAS System for Windows Release 9.4; SAS Institute: Cary, NC, USA, 2016.

47. Abba, S.; Oluskin, J.; Dare, S.S.; Mohammed, Y.G.; Ajayi, A.M.; Okpanachi, A.O. Comparison of the attraction index of male and female Drosophila melanogaster to varying odorant substances. Curr. Research J. Biol. Sci. 2012, 4, 655-659.

48. Box, G.E.P.; Hunter, W.G.; Hunter, J.S. Statistics for Experimenters. An Introduction to Design, Data Analysis, and Model Building; John Wiley \& Sons: New York, NY, USA, 1978.

Sample Availability: Samples of the compounds 1-5 are available from the authors.

(C) 2019 This work was produced by the US government employees and is in the public domain in the US. Licensee MDPI, Basel, Switzerland. This article is an open access article distributed under the terms and conditions of the Creative Commons Attribution (CC BY) license (http://creativecommons.org/licenses/by/4.0/). 